EMIR GANIĆ, Ph.D. ${ }^{1}$

(Corresponding author)

E-mail: e.ganic@sf.bg.ac.rs

JURICA IVOŠEVIĆ, Ph.D. ${ }^{2}$

E-mail: jivosevic@fpz.unizg.hr

BOJANA MIRKOVIĆ, Ph.D. ${ }^{1}$

E-mail: b.mirkovic@sf.bg.ac.rs

${ }^{1}$ University of Belgrade

Faculty of Transport and Traffic Engineering

Vojvode Stepe 305, 11000 Belgrade, Serbia

${ }^{2}$ University of Zagreb

Faculty of Transport and Traffic Sciences

Vukelićeva 4, 10000 Zagreb, Croatia
Traffic and Environment (Ecology) Original Scientific Paper Submitted: 10 Sep. 2020 Accepted: 12 Jan. 2021

\title{
IMPACT OF AIRCRAFT NOISE ON COMMUNITIES NEAR BELGRADE AIRPORT
}

\begin{abstract}
The aim of this research was to examine the impact of aircraft noise on communities near the Belgrade Airport by conducting short-term noise measurements. Apart from the noise abatement procedure published in the Aeronautical Information Publication for Belgrade Airport, there are still neither publicly available reports of the actual efforts made towards the aircraft noise reduction nor the description of the current noise situation. In order to estimate the current noise situation, eighteen aircraft overflight noise measurements were taken in two settlements in specific sound-sensitive community areas around the Belgrade Airport. The results showed that level differences between background noise and aircraft overflights were higher than $10 \mathrm{~dB}$ for each measurement and could be considered significant. Furthermore, preliminary compatibility analysis with acoustic zoning was performed. Average daily noise levels were estimated from these short-term measurements and were compared to legal noise limits for different acoustic zones. The results indicate that in some cases noise levels exceed the legal threshold, which should encourage land use planners to include the issue of Belgrade acoustic zoning on the agenda, but also prompt Belgrade Airport to implement continuous noise and flight tracks monitoring.
\end{abstract}

\section{KEYWORDS}

aircraft external noise; Belgrade Airport; noise measurement; noise monitoring; flight tracks monitoring; noise abatement procedures.

\section{INTRODUCTION}

Noise is an unwanted sound which has a certain intensity, is distinguished from other sounds, and is loud enough to be heard. In common language, the word noise means any unwanted sound. Aircraft noise is noise produced by any aircraft or its components, during various flight phases: on the ground while parked and connected to external power sources such as ground power units, while taxiing, on run-up from propeller and jet exhaust, during take-off and landing, underneath and lateral to departure and arrival paths, or while en route. Noise characteristics and levels depend on the aircraft type and the respective flight phase.

The highest allowed values of the external noise generated by aircraft are precisely defined in Annex 16 - Environmental Protection - Volume I - Aircraft Noise of the International Civil Aviation Organization (ICAO). The certification noise levels, which are established in compliance with the ICAO Annex 16, Volume I, are approved by the European Aviation Safety Agency (EASA) as part of the aircraft certification process where the type certificate data sheet for noise (TCDSN) is issued by EASA. Brand new aircraft may not become operational unless the above-mentioned standards are met.

The principal sources of aircraft noise are the engines and the airframe of an aircraft, with engines being by far the more significant source of noise [1]. The aviation industry was and will be continuously challenged to reduce environmental impact in the face of constant (although temporarily interrupted) increase in demand. Flightpath 2050 Europe's Vision for Aviation [2] sets the goal to reduce the perceived noise emission of flying aircraft by $65 \%$, relative to typical new aircraft in 2000 . 
Over the years, various efforts have been made to mitigate adverse effects of aircraft noise. At the international level, the ICAO has presented the socalled "Balanced approach" [3] to aircraft noise management that consists of identifying the noise problem at an airport and analyzing various measures available to reduce noise, with the goal of addressing the noise problem in the most cost-effective manner. At the European level, Environmental Noise Directive 2002/49/EC (END) [4] has been introduced for the assessment and management of environmental noise. The Directive introduced the obligation of strategic noise map development and subsequently implementation of noise action plans, which have been successfully put into practice at many airports [5-9]. Furthermore, the European Commission established common noise assessment methods (CNOSSOS-EU) [10] according to Directive 2002/49/EC, to improve the consistency and the comparability of noise assessment results across the EU member states, providing a harmonized framework for assessment of each noise source covered by END [11].

In addition to noise modelling efforts, another pivotal aspect in assessing the airport noise impact includes aircraft noise measurements. Even though some noise measurements around airports are performed to estimate the impact of airport noise on property market values [12], the main goal of most noise measurements is to assess the negative environmental impact of aircraft noise on people's health and wellbeing [13-15]. Some research papers investigate the impact of aircraft noise on sleep quality [16], while others conduct short-term measurements to verify the results obtained by noise models [17].

Several studies address aircraft noise at the Belgrade Airport, but most of them were completed more than 30 years ago. Four studies [18-21] completed in the period 1975-1990 addressed the issues of noise measurements, analyses, zoning, and mitigation measures in the vicinity of the Belgrade Airport. It is interesting to notice that it was proposed as early as then to immediately discontinue further development of Ledine settlement and to gradually depopulate this location which nowadays represents a major problem for the Belgrade Airport [22]. These studies also consider noise exposure of the following populated areas in Belgrade: Blok 45, Blok 60, Blok 70, Banovo brdo, and Surčin. Single-runway layout (as it is now) and two parallel independent runway configurations were analyzed. Study [21] analyzes noise exposure for years 1990 and 2000 . In 1990, the number of operations was similar to the operation numbers for the period 2007-2012 (approximately 43 thousand operations per year); however, louder aircraft were flying. Today, with somewhat greater number of operations and much quieter aircraft, noise contours cover smaller areas but certainly affect larger number of people since Ledine and Surčin significantly expanded and became more populated in the meantime [22]. The more recent noise measurement study performed around the Belgrade Airport addressed the impact of aircraft noise on quiet areas [23]. In this study, several short-term measurements conducted at one site intended for relaxation of people in Belgrade showed that the level difference between background noise and aircraft overflights ranged from $11.5 \mathrm{~dB}$ to $28.1 \mathrm{~dB}$, which was considered to be significant. The authors gave several recommendations on how to preserve quiet areas.

Since 2014, the Belgrade Airport serves more than 50 thousand operations a year and resultantly has a legal obligation to measure noise exposure, prepare strategic noise maps, and define corresponding action plans. The deadline for strategic noise mapping was postponed on several occasions (2012, 2015, 2020). Serbian Ministry for Environmental Protection should define strategic noise maps by the end of 2020 and use the maps as the basis to determine special protection locations and noise mitigation action plans. According to the Civil Aviation Directorate of the Republic of Serbia, city areas exposed to aircraft noise (in 2016) are: Bežanijska kosa, Blokovi, Čukarička padina, Banovo brdo, Žarkovo, Senjak, Rakovica, and Dedinje. Illegally built structures in close vicinity of the airport (expansion of Ledine settlement) suffer the most significant exposure to aircraft noise.

This research examines the noise impact on communities at two locations near the Belgrade Airport, which are located on the opposite sides of the runway. Ledine is affected by take-offs from runway 12 and landings to runway 30, while Ugrinovci is affected by take-offs from runway 30 and landings to runway 12 . Measurements were performed during take-off and landing procedures and the most significant results are presented herein. 
The paper is organized as follows. Section 2 describes the methodology, particularly emphasizing the selected measurement locations, equipment used, air traffic data, and meteorological situation. Through the analyses of the measured values combined with the air traffic data, Section 3 provides the results and discussion of the results. Section 4 contains conclusions, remarks, and ideas for future work.

\section{METHODOLOGY}

To analyze the impact of aircraft noise on residents living near the airport, several steps were performed. Measurement locations were chosen, and the measurements were completed. Subsequently, air traffic data and meteorological data were collected and paired with the measured data for every flight. A brief description of every step is given below.

\subsection{Measurement locations}

Selection of a measurement site is critical in obtaining accurate and useful sound data and should, wherever possible, be in line with the requirements set out in section 4.2 of ISO 20906 [24] and Annex C of ISO 1996-2 [25]. The standards describe selection of sound measurement locations as a two-stage process that should be considered in early stages of the measurement plan development, once the measuring objectives have been clearly identified. The first stage involves a general measuring location which is selected based on the measuring objectives. In the second stage, within the general area, a specific measurement location is selected based on practical and other considerations, such as: interference from other sound sources, terrain and building obstructions, the likely uncertainty of the measurements, etc. The requirements of the above-mentioned standards are quite stringent, and it may not always be possible to meet all the requirements and identify a secure site in the desired area [26].

Given that the measuring objective of this study is to obtain accurate sound information in specific sound-sensitive community areas around the airport, the settlements Ugrinovci and Ledine near the Belgrade Airport were selected as the general area. Runway 12 was in use $2 / 3$ of time at the Belgrade Airport, but since take-off operations from that runway fly over the city, it is recommended to use runway 30 whenever meteorological conditions allow it, especially during night time (22:00 to $05: 00$ ), and it is forbidden for IL-76 and aircraft below Stage 3 Noise Certificate to take off from runway 12 (see AIP LYBE AD 2.21). Ledine and Ugrinovci are located on the opposite sides of the runway - Ledine in the dominant direction in use $122^{\circ}$ and Ugrinovci in the direction $302^{\circ}$, which is less used, but it is preferred for take-off operations by noisier aircraft. Specific measurement sites within general area are selected, considering practical and other aspects. Two locations exactly beneath the expected departure and arrival flight trajectories were chosen as the ones with the highest exposure to aircraft noise. Overall characteristics of the selected locations are described in Table 1.

Table 1 -Description of the selected measurement locations

\begin{tabular}{||l|c|c||}
\hline \multicolumn{1}{|c|}{$\begin{array}{c}\text { Measurement } \\
\text { location no. }\end{array}$} & ML1 & ML2 \\
\hline \hline Settlement & Ugrinovci & Ledine \\
\hline Latitude & $44^{\circ} 51^{\prime} 56.1^{\prime \prime} \mathrm{N}$ & $44^{\circ} 48^{\prime} 21.9^{\prime \prime} \mathrm{N}$ \\
\hline Longitude & $20^{\circ} 12^{\prime} 20.2^{\prime \prime} \mathrm{E}$ & $20^{\circ} 20^{\prime} 09.5^{\prime \prime} \mathrm{E}$ \\
\hline Elevation & $73 \mathrm{~m}$ & $98 \mathrm{~m}$ \\
\hline $\begin{array}{l}\text { Distance from runway } \\
12 \text { threshold }\end{array}$ & $8001 \mathrm{~m}$ & $4215 \mathrm{~m}$ \\
\hline $\begin{array}{l}\text { Distance from runway } \\
30 \text { threshold }\end{array}$ & $11000 \mathrm{~m}$ & $1220 \mathrm{~m}$ \\
\hline $\begin{array}{l}\text { Distance from } \\
\text { reflecting surfaces* }\end{array}$ & $51 \mathrm{~m}$ & $10 \mathrm{~m}$ \\
\hline
\end{tabular}

*other than ground surface

The first selected measurement location (ML1) is in the settlement Ugrinovci around $8 \mathrm{~km}$ from the runway 12 threshold at the elevation of $73 \mathrm{~m}$, with the nearest residential house located at $51 \mathrm{~m}$. The second measurement location (ML2) is in the settlement Ledine around $1.2 \mathrm{~km}$ from the runway 30 threshold at the elevation of $98 \mathrm{~m}$, with the nearest residential house located at $10 \mathrm{~m}$. To provide minimum uncertainty in the sound level measurements, all acoustically relevant reflecting surfaces other than the ground were at least $10 \mathrm{~m}$ away from the microphone, which was in accordance with the ISO 20906. According to the results of the Census of Population, Households and Dwellings in the Republic of Serbia carried out in October 2011, the population in settlements Ugrinovci and Ledine was 10,807 and 6,813 respectively [27]. It is worth mentioning that the actual population of the settlement Ledine is much greater than the official numbers, due to unplanned inhabitation and illegal expansion in the near proximity of the airport [28]. Figure 1 


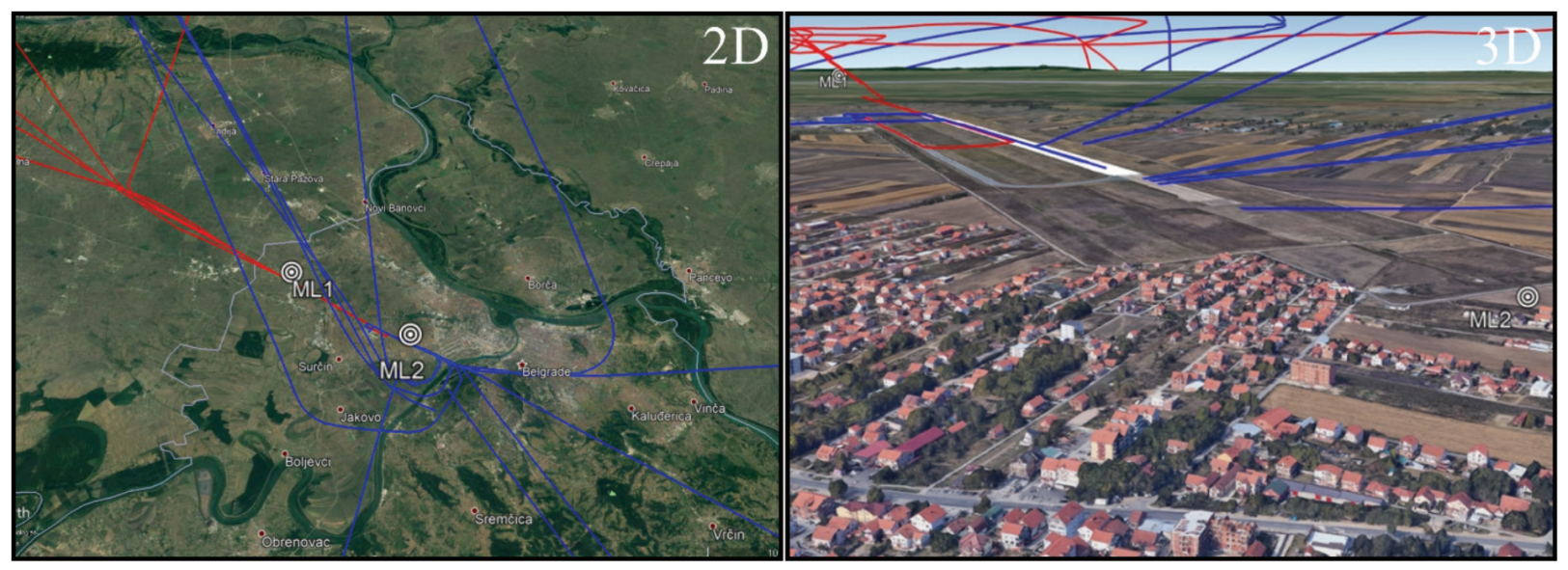

Figure 1 - Flight tracks in 2D and 3D (source: Flightradar24.com, using Google Earth)

shows the positions of the measurement locations in relation to flight trajectories and proximity of residential areas.

\subsection{Meteorological data}

The measurements were performed on Saturday, 25 January 2020 , from 10:55 a.m. to 1:50 p.m. The weather was calm, with little wind and mostly no clouds. All meteorological data were collected from publicly available METAR reports for the Belgrade Airport for the observed period. The wind direction was variable, ranging between 290 degrees and 30 degrees with reference to true north. The wind speed ranged between $0.5 \mathrm{~m} / \mathrm{s}$ and $2 \mathrm{~m} / \mathrm{s}$, which can be considered a light or gentle breeze. The temperature ranged between $2{ }^{\circ} \mathrm{C}$ and $10^{\circ} \mathrm{C}$ during the measurement period.

\subsection{Air traffic data}

Due to the meteorological situation and the scheduled traffic at the airport, runway 12 was in use during the measurement period, which meant that aircraft were departing to southeast and were arriving from northwest. Therefore, it was not possible to capture both departures and arrivals at one location at the same time. During the first measurement period (MP1) at the ML1, five arrivals were recorded. Since the scheduled traffic forecasted more departures in the coming period, the measurement equipment was moved to the ML2 where, during the second measurement period (MP2), 13 departures were recorded. Table 2 shows that 18 arrival and departure operations were performed by nine aircraft types. For the purposes of comparison, Table 2 also shows the data for each aircraft type such as: type and number of engines, maximum take-off weight (MTOW), seat capacity, and ICAO wake turbulence category (WTC). More than half of the operations were performed by jet engine aircraft, while the most frequent aircraft type with four operations recorded during the measurement was ATR 72-202 with turboprop engine along with the Airbus A320 with the same number of operations. Flight details such as ground speed, position, track, altitude, and vertical speed were obtained from the Flightradar24 website (www.flightradar24.com) and flight tracks for most of the flights are graphically shown in Figure 1.

Arrival trajectories are marked red, while departure operations are marked blue. For each flight where the flight tracks were available, height and lateral distance was calculated as the difference between the aircraft height at the moment of overflight and elevation of measurement location, taking into account the difference between the elevation of the airport, which was $102 \mathrm{~m}$, and the elevation of the measurement location. At the ML1, the height ranged from $449 \mathrm{~m}$ to $509 \mathrm{~m}$ while lateral distance took values from $122 \mathrm{~m}$ to $155 \mathrm{~m}$, which was expected for arrival aircraft flight profiles. For departure operations, flight profiles could significantly differ between aircraft due to different aircraft performances during take-off and early turns after departure. At the ML2, located just $1 \mathrm{~km}$ away from runway 30 threshold, the height ranged from 202 $\mathrm{m}$ to $439 \mathrm{~m}$ and lateral distance between $46 \mathrm{~m}$ and $81 \mathrm{~m}$.

For seven departure operations, calculation of height and lateral distance was not possible since flight tracks were incomplete. Figure 1 shows that parts of some flight trajectories at the moment of 
Ganić E, Ivošević J, Mirković B. Impact of Aircraft Noise on Communities Near Belgrade Airport

Table 2 - Arrival and departure operations

\begin{tabular}{|c|c|c|c|c|c|c|c|c|c|c|}
\hline No & $\mathrm{O}^{1}$ & Aircraft type (ICAO code) & $\mathrm{ET}^{2}$ & $\mathrm{NE}^{3}$ & MTOW $^{4}$ & $\mathrm{SC}^{5}$ & WTC $^{6}$ & $\mathrm{ML}^{7}$ & $\mathrm{H}^{8}$ & $\mathrm{LD}^{9}$ \\
\hline 1 & A & ATR 72-202 (AT72) & TP & 2 & 21500 & 74 & M & 1 & 485 & 155 \\
\hline 2 & $\mathrm{~A}$ & ATR 72-500 (AT75) & TP & 2 & 21500 & 74 & M & 1 & 502 & 144 \\
\hline 3 & A & Airbus A319-132 (A319) & $\mathrm{J}$ & 2 & 64000 & 160 & M & 1 & 449 & 122 \\
\hline 4 & A & ATR 72-202 (AT72) & $\mathrm{TP}$ & 2 & 21500 & 74 & M & 1 & 509 & 137 \\
\hline 5 & A & Airbus A320-214 (A320) & $\mathrm{J}$ & 2 & 74000 & 180 & M & 1 & 462 & 122 \\
\hline 6 & $\mathrm{D}$ & Cessna $172(\mathrm{C} 172)$ & $P$ & 1 & 1100 & 3 & $\mathrm{~L}$ & 2 & $\mathrm{~N} / \mathrm{A}$ & N/A \\
\hline 7 & $\mathrm{D}$ & Hawker Beechcraft 400XP (BE40) & $\mathrm{J}$ & 2 & 7400 & 8 & M & 2 & $\mathrm{~N} / \mathrm{A}$ & $\mathrm{N} / \mathrm{A}$ \\
\hline 8 & $\mathrm{D}$ & Airbus A320-214 (A320) & $\mathrm{J}$ & 2 & 74000 & 180 & M & 2 & 304 & 51 \\
\hline 9 & $\mathrm{D}$ & Airbus A320-232 (A320) & $\mathrm{J}$ & 2 & 74000 & 180 & M & 2 & 305 & 81 \\
\hline 10 & $\mathrm{D}$ & Boeing 737-8KN (B738) & $\mathrm{J}$ & 2 & 78200 & 189 & M & 2 & 202 & 52 \\
\hline 11 & $\mathrm{D}$ & Bombardier CRJ-900LR (CRJ9) & $\mathrm{J}$ & 2 & 36500 & 90 & M & 2 & N/A & N/A \\
\hline 12 & $\mathrm{D}$ & Airbus A320-232 (A320) & $\mathrm{J}$ & 2 & 74000 & 180 & M & 2 & 273 & 61 \\
\hline 13 & $\mathrm{D}$ & Airbus A330-202 (A332) & $\mathrm{J}$ & 2 & 23000 & 406 & $\mathrm{H}$ & 2 & 268 & 57 \\
\hline 14 & $\mathrm{D}$ & ATR 72-202 (AT72) & TP & 2 & 21500 & 74 & $\mathrm{M}$ & 2 & N/A & N/A \\
\hline 15 & $\mathrm{D}$ & ATR 72-500 (AT75) & $\mathrm{TP}$ & 2 & 21500 & 74 & $\mathrm{M}$ & 2 & N/A & $\mathrm{N} / \mathrm{A}$ \\
\hline 16 & $\mathrm{D}$ & Airbus A319-132 (A319) & $\mathrm{J}$ & 2 & 64000 & 160 & M & 2 & 439 & 46 \\
\hline 17 & $\mathrm{D}$ & ATR 72-202 (AT72) & $\mathrm{TP}$ & 2 & 21500 & 74 & $\mathrm{M}$ & 2 & N/A & N/A \\
\hline 18 & $\mathrm{D}$ & ATR 72-500 (AT75) & $\mathrm{TP}$ & 2 & 21500 & 74 & $\mathrm{M}$ & 2 & N/A & $\mathrm{N} / \mathrm{A}$ \\
\hline
\end{tabular}

1 Operation type: A - Arrival, $D-$ Departure

2 Engine type: TP - Turboprop, J-Jet, P - Piston

3 Number of engines

4 Maximum take-off weight [kg], source: ICAO Doc. 7100 and http://www.flugzeuginfo.net

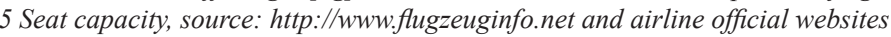

6 ICAO wake turbulence category: $L$ - Light, $M$ - Medium, $H$ - Heavy

7 Measurement location: 1 - Ugrinovci, 2 - Ledine

8 Height $[\mathrm{m}]$, representing the vertical distance above Aerodrome Reference Point (ARP)

9 Lateral distance $[\mathrm{m}]$

aircraft overflight were missing, which was probably because the ADS-B/Mode S transponder was not turned on from the beginning of the departure.

\subsection{Measurement equipment}

Class 1 sound analyzer was used for the noise measurements, and the recorded data were analyzed with a proprietary data analysis software.

The measurement equipment was used to calculate the following indicators in this study:

- LAeq, which represents the A-weighted, equivalent continuous sound level in decibels measured over a stated period of time;

- LAE, which represents the A-weighted sound exposure levels, which is the total sound energy integrated over the measurement period;

- LAFmax and LAFmin, as maximum and minimum levels with A-weighted frequency response and fast time constant; and

- LAFn, as the level of A-weighted noise exceeded for $\mathrm{n} \%$ of the measurement period, calculated by statistical analysis - with $\mathrm{n}$ ranging between $0.01 \%$ and $99.99 \%$ (herein, five levels are shown: LAF5, LAF10, LAF50, LAF90, and LAF95).

\section{RESULTS AND DISSCUSION}

The aim of this set of measurements was to capture aircraft noise events, determine all the relevant parameters including aircraft noise levels, and to compare them to the background noise levels.

Apart from the two measurements carried out to establish background noise levels at the ML1 and the ML2, 18 short-term measurements were conducted, one for each overflight. Measurement results for background and aircraft overflight noise levels are shown in Table 3.

Measurements are numbered M1 to M20, with M1 and M7 representing background noise at the ML1 and the ML2 respectively, since there were no aircraft overflights during the measurement time. Among 18 overflights recorded, measurements M2 to M6 represent arrival operations, while measurements M8 to M20 represent departure operations. 
Ganić E, Ivošević J, Mirković B. Impact of Aircraft Noise on Communities Near Belgrade Airport

Table 3 -Measurement results

\begin{tabular}{|c|c|c|c|c|c|c|c|c|c|c|c|}
\hline Code & $\mathrm{T}(\mathrm{s})$ & LAeq & LAE & LAFmax & LAFmin & $\begin{array}{c}\text { LAF } \\
5.0\end{array}$ & $\begin{array}{l}\text { LAF } \\
10.0\end{array}$ & $\begin{array}{l}\text { LAF } \\
50.0\end{array}$ & $\begin{array}{l}\text { LAF } \\
90.0\end{array}$ & $\begin{array}{l}\text { LAF } \\
95.0\end{array}$ & $\begin{array}{c}\Delta \mathrm{LA} \\
\mathrm{eq}\end{array}$ \\
\hline \multicolumn{12}{|c|}{ Measurements conducted at ML1 } \\
\hline M1 & 60 & 50.5 & 68.3 & 57.8 & 41.6 & 54.0 & 52.4 & 49.8 & 48.6 & 48.4 & / \\
\hline M2 & 60 & 64.5 & 82.3 & 72.8 & 51.5 & 71.7 & 70.6 & 57.2 & 53.1 & 52.8 & 14.0 \\
\hline M3 & 60 & 62.9 & 80.7 & 71.3 & 50.3 & 69.1 & 68.6 & 55.4 & 51.3 & 51.0 & 12.4 \\
\hline M4 & 60 & 65.8 & 83.6 & 74.1 & 50.2 & 72.6 & 71.6 & 58.1 & 51.9 & 51.5 & 15.3 \\
\hline M5 & 60 & 64.8 & 82.5 & 73.7 & 52.3 & 71.5 & 70.5 & 58.5 & 53.8 & 53.5 & 14.3 \\
\hline M6 & 60 & 64.5 & 82.3 & 73.0 & 48.7 & 71.4 & 70.5 & 56.6 & 50.2 & 49.9 & 14.0 \\
\hline \multicolumn{12}{|c|}{ Measurements conducted at ML2 } \\
\hline M7 & 60 & 33.7 & 51.5 & 51.4 & 28.7 & 36.1 & 35.2 & 31.5 & 29.6 & 29.3 & l \\
\hline M8 & 38 & 52.9 & 68.7 & 59.9 & 41.8 & 57.7 & 57.1 & 51.9 & 43.2 & 42.8 & 19.2 \\
\hline M9 & 60 & 77.4 & 95.2 & 88.2 & 52.7 & 85.7 & 83.8 & 63.6 & 56.4 & 55.3 & 43.7 \\
\hline M10 & 56 & 73.9 & 91.5 & 84.6 & 42.1 & 82.7 & 79.7 & 58.4 & 45.5 & 44.6 & 40.2 \\
\hline M11 & 60 & 74.5 & 92.2 & 84.6 & 42.0 & 82.9 & 80.6 & 55.6 & 45.1 & 44.1 & 40.8 \\
\hline M12 & 50 & 73.6 & 90.6 & 84.1 & 37.4 & 81.6 & 79.8 & 57.6 & 42.5 & 40.4 & 39.9 \\
\hline M13 & 80 & 78.1 & 97.1 & 92.2 & 40.0 & 86.6 & 80.1 & 52.2 & 43.7 & 41.9 & 44.4 \\
\hline M14 & 68 & 74.6 & 92.9 & 85.3 & 39.8 & 83.9 & 79.6 & 53.6 & 44.4 & 42.9 & 40.9 \\
\hline M15 & 60 & 82.6 & 100.4 & 94.3 & 43.3 & 91.6 & 87.8 & 58.1 & 46.5 & 44.8 & 48.9 \\
\hline M16 & 60 & 64.4 & 82.1 & 74.6 & 38.4 & 72.2 & 70.4 & 56.2 & 41.3 & 40.5 & 30.7 \\
\hline M17 & 60 & 59.5 & 77.3 & 68.5 & 42.3 & 65.1 & 64.2 & 55.2 & 48.2 & 47.1 & 25.8 \\
\hline M18 & 60 & 70.1 & 87.9 & 78.6 & 40.3 & 77.2 & 76.4 & 61.3 & 46.7 & 44.1 & 36.4 \\
\hline M19 & 60 & 64.0 & 81.8 & 74.2 & 36.3 & 71.6 & 69.6 & 56.0 & 42.4 & 39.8 & 30.3 \\
\hline M20 & 60 & 65.1 & 82.9 & 75.6 & 34.5 & 73.0 & 71.1 & 55.9 & 43.0 & 39.0 & 31.4 \\
\hline
\end{tabular}

The integration period used for calculating the LAeq and other indicators given in Table 3 is equal to the entire duration of each measurement $(\mathrm{T})$ which represents the actual overflight time. For most of the overflights, period of 60 seconds was enough to capture the entire aircraft noise event. The last column in Table 3 ( $\triangle$ LAeq) represents the difference between LAeq of the event, which in this case is the aircraft overflight, and LAeq of the background noise level at the given location.

\subsection{Background noise levels}

To obtain background noise levels at given locations, short-term measurements were conducted during periods without aircraft overflights and the results are shown in Figure 2. There was no need for longer continuous measurement, since all the measured noise levels were quite uniform during the entire period.

Based on the noise levels from M1 measurement (Figure $2 a$ ), LAeq $=50.5 \mathrm{~dB}$ was adopted as background noise level for the ML1. LAF90 or LAF95 could also be used as indicators of background noise levels, while LAF10 or LAF5 are sometimes used to indicate the level of noise events. The values of LAF95 for 5 measurements at the ML1 (M2-M6) ranged from $49.9 \mathrm{~dB}$ to $53.5 \mathrm{~dB}$ with an average value of $51.7 \mathrm{~dB}$, which was close to the adopted background noise.

The same approach was applied for the ML2, where the noise level from the M7 measurement (Figure $2 b$ ), $\mathrm{LAeq}=33.7 \mathrm{~dB}$ was adopted as the background noise level. However, the average value of LAF95 for 13 measurements at the ML2 (M8-M20) was $43.6 \mathrm{~dB}$, which was higher than the adopted background noise level. This could be explained by comparing the noise levels of aircraft overflight at the ML1 for measurement M3 (Figure 3a) with the noise levels of aircraft overflight at the ML2 for measurement M11 (Figure 3b). Due to extremely low background noise levels at the ML2, the aircraft noise is considered dominant for some time after immediate aircraft overflight. The obtained background noise level could be explained by the fact that the ML2 is located in a dead-end street that 


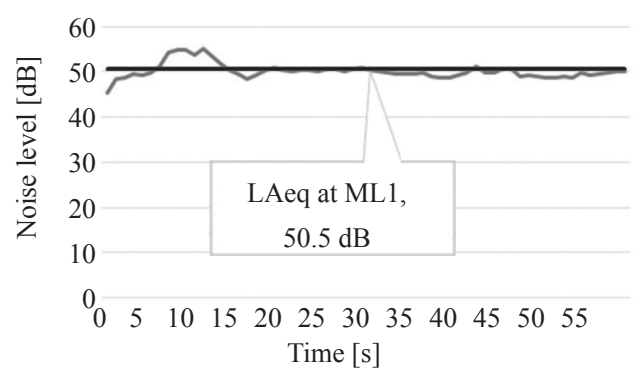

a)

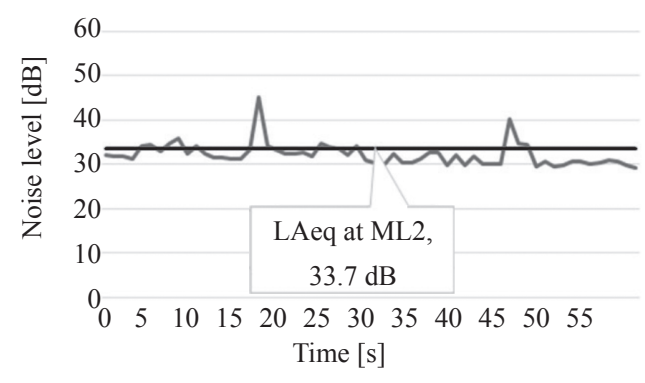

b)

Figure 2 - Background noise measurements

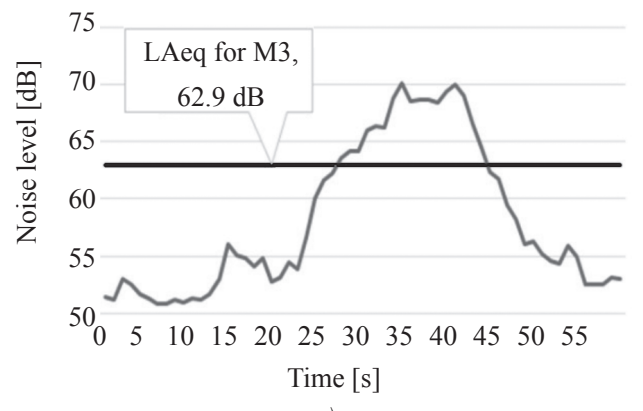

a)

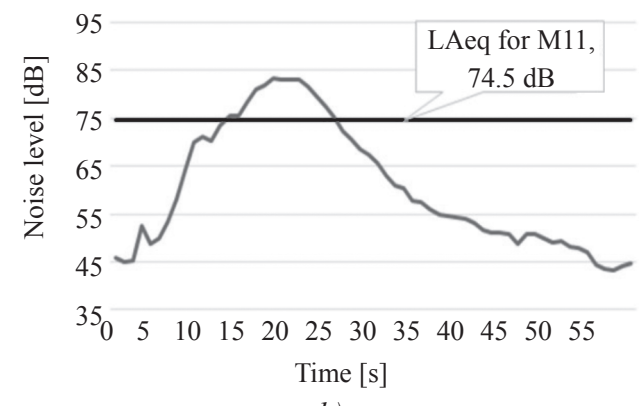

b)

Figure 3 - Aircraft overflight noise measurements

serves only a dozen houses in the area that could be classified as rural. If the measurement period at the ML2 had been longer by at least 30 seconds, the aircraft noise levels would have merged with the background noise levels, providing smaller values of LAF95. Nevertheless, the selected time period does not significantly affect the LAeq and LAE noise levels obtained, since the loudest part of each aircraft overflight has already been captured.

\subsection{Overflight frequency and noise levels}

During the measurements at the ML1, the minimum time between two overflights was 2.3 minutes while the maximum gap was 18 minutes with an average value of 8.7 minutes between two overflights. Frequency of aircraft overflights at the ML2 was a bit higher than at the ML1. The minimum time between two overflights was 1.2 minutes, while the maximum gap was 25 minutes with an average value of 6.7 minutes between two overflights. Figure 4 shows that the gap between most of the overflights at both locations was up to five minutes.

Based on the measurement results presented in Table 3, Figure 5 shows that for most of the aircraft overflights (eight of them) LAeq ranges from $60 \mathrm{~dB}$ to $70 \mathrm{~dB}$, while there are no overflights with LAeq lower than $50 \mathrm{~dB}$ or higher than $90 \mathrm{~dB}$. As expected, LAFmin does not exceed $60 \mathrm{~dB}$ for any overflight, while for most overflights (13) it is less than $50 \mathrm{~dB}$. LAFmax exceeds $80 \mathrm{~dB}$ during seven overflights, while for nine overflights it ranges between $70 \mathrm{~dB}$

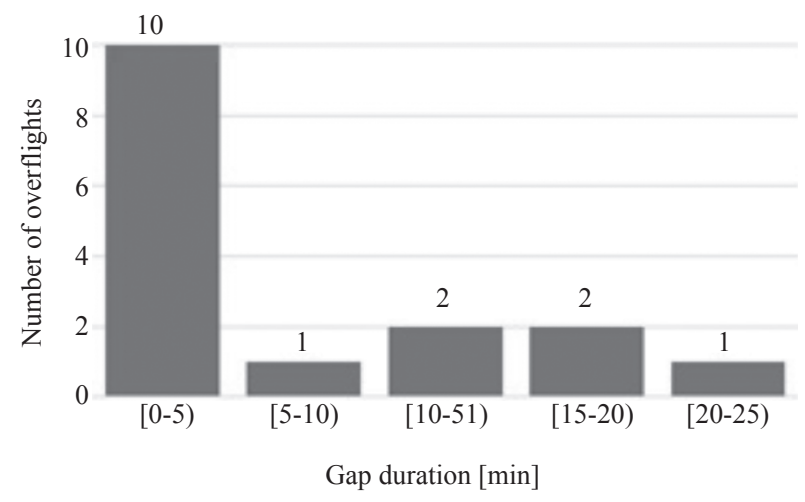

Figure 4-Gap between two overflights

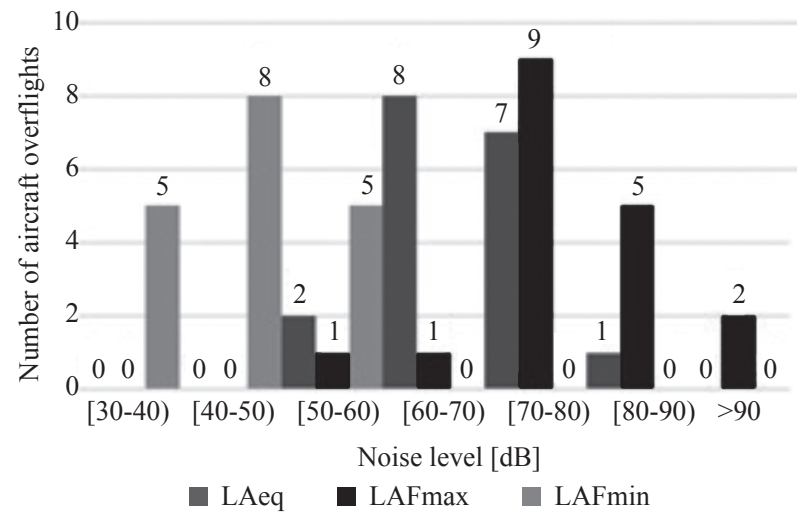

Figure 5 -Aircraft overflights per noise indicator cluster 
and $80 \mathrm{~dB}$. These levels refer to the entire period of each measurement which also includes short periods before and after an actual overflight.

Table 3 shows that $\triangle$ LAeq ranges from $12.4 \mathrm{~dB}$ for $\mathrm{M} 3$ to $48.9 \mathrm{~dB}$ for M15. The average $\Delta \mathrm{LAeq}$ is $18.2 \mathrm{~dB}$. Due to the logarithmic scale, with each increase of $6 \mathrm{~dB}$ the sound pressure is doubled and such change in noise levels is obvious. Having in mind that the level difference between background noise and aircraft overflights is higher than $10 \mathrm{~dB}$ for each measured event, aircraft noise in the observed communities around the airport should be considered significant.

In the case of measurement M15, the level difference of $48.9 \mathrm{~dB}$ reveals that the sound pressure of aircraft overflight is 278.6 times higher than the sound pressure of the background noise. Such a result prompted the authors to conduct an informal interview with residents living near the measurement locations to investigate their subjective reactions to aircraft noise.

One of the residents that lives near the ML1 reported a significant negative impact of aircraft noise, especially outside the house between the courtyard buildings. These high levels are primarily due to multiple reflections of sound. Residents living near the ML2, especially those who live closest to the runway threshold, stated that they had allegedly suffered damage to their house roofs, which was in their opinion due to vibrations resulting from the excessive noise of the aircraft flying close to their homes. These high sound intensities are due to high levels of take-off thrust during departure and small distance from the residential area which is directly below the departure path. In addition to these interesting impressions, all the responses collected testify to a noticeable negative impact of aircraft noise upon the living conditions in communities near the airport. However, before drawing any conclusions regarding the aircraft noise impact on the subjective wellbeing of the residents living near the Belgrade Airport, a more comprehensive study is needed.

\subsection{Average daily noise levels estimation}

All short-term noise measurements were carried out with the aim to assess the noise levels of single aircraft overflights and to compare them to background noise levels. Nevertheless, additional comparison to the legal noise limits can be made by estimating the average daily noise levels from the measured values. This is done by introducing two assumptions. Firstly, the average noise levels for periods without aircraft overflights are presumed to be equal to the measured background noise levels. Secondly, aircraft overflights during the measurement period are presumed to reflect the representative average daily traffic. The second assumption can be checked by comparing the actual traffic during the measurement period to the average monthly and yearly traffic.

Based on the annual traffic, the average number of operations per hour during a 12-hour period of the day (06-18h) is determined. If this average number is relatively close to the average number of operations per hour during the measurement period and if the fleet mix reflects the representative average daily traffic, then it is assumed that the LAeq noise levels obtained from measurements can be considered as noise indicator $\mathrm{L}_{\text {day }}$ and therefore compared to legal noise limits.

Based on the data available at the EUROCONTROL Statistics and Forecast Service, STATFOR Dashboard [29], the Belgrade Airport had 160 average daily flights during January 2020, with approximately equal number of departure and arrival operations. Operations during the 12-hour day period account for approximately $64.07 \%$ of all operations (based on the detailed data for the busiest day in 2019). This indicates that, on average, there are 8.54 operations per hour at the Belgrade Airport during the day period.

The first measurement period (45 minutes) included 5 operations, which corresponds to 6.67 operations per hour, and this is slightly lower than the average hourly operation value for January 2020 . The second measurement period ( 90 minutes) consisted of 13 operations corresponding to 8.67 hourly operations, which is almost equal to the January 2020 average value.

Compared to the yearly average traffic shown in Figure 6, which for the year 2019 was 194 operations per day or approximately 10.36 operations per hour for 12-hour day periods, it could be seen that the observed traffic during both measurement periods was below average, indicating that the measured noise levels would be below the yearly average. This is understandable, given that the average number of operations in January is lower than the average number of operations for the whole year. 


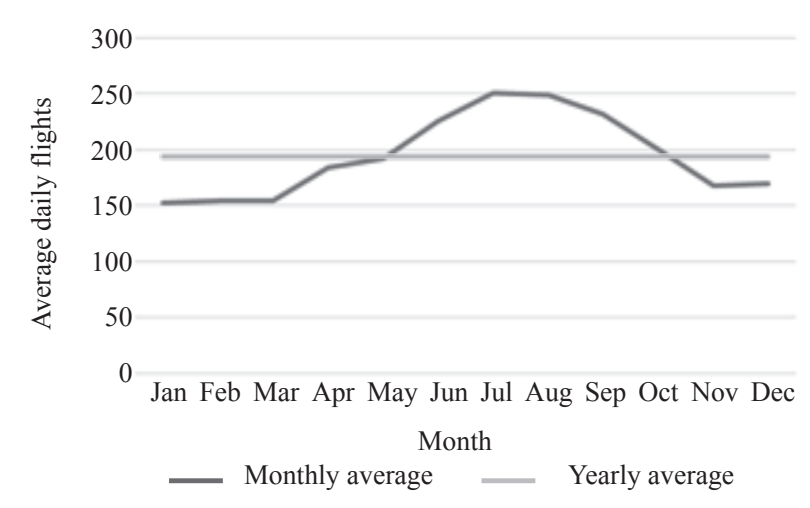

Figure 6-Average number of daily flights, year 2019, source: STATFOR [27]

Apart from flight frequency and type of operation, fleet mix is a pivotal factor in assessing whether the observed traffic could be representative. Table 4 shows the number of departures per aircraft type at the Belgrade Airport for the year 2019. STATFOR database provides only the number of departures and only for aircraft types with frequency of at least four flights per month. All aircraft types recorded during both measurement periods are highlighted in grey in Table 4. Having in mind that $63.7 \%$ of all departures at the Belgrade Airport during the year 2019 were performed by four most frequent aircraft types (A319, A320, AT72, and AT75) and that the same four aircraft types

Table 4 - Total departures per aircraft type [29]

\begin{tabular}{|c|c|c||}
\hline $\begin{array}{c}\text { ICAO Aircraft type } \\
\text { code }\end{array}$ & $\begin{array}{c}\text { Number of } \\
\text { departures }\end{array}$ & $\begin{array}{c}\text { Percentage of all } \\
\text { departures }\end{array}$ \\
\hline \hline A319 & 8223 & $23.8 \%$ \\
\hline A320 & 7607 & $22.0 \%$ \\
\hline AT75 & 3100 & $9.0 \%$ \\
\hline AT72 & 3080 & $8.9 \%$ \\
\hline E195 & 1411 & $4.1 \%$ \\
\hline C56X & 1339 & $3.9 \%$ \\
\hline B738 & 1296 & $3.7 \%$ \\
\hline B733 & 1282 & $3.7 \%$ \\
\hline A321 & 1106 & $3.2 \%$ \\
\hline DH8D & 634 & $1.8 \%$ \\
\hline CRJ9 & 633 & $1.8 \%$ \\
\hline AT45 & 398 & $1.2 \%$ \\
\hline C55B & 393 & $1.1 \%$ \\
\hline F100 & 352 & $1.0 \%$ \\
\hline All other aircraft & 3724 & Less than $1 \%$ \\
types & & \\
\hline
\end{tabular}

represent $72.2 \%$ of the recorded operations during the measurement, the observed traffic may be considered representative in terms of fleet mix.

\subsection{Measured vs. legal noise limit values}

If the two above-mentioned assumptions are adopted, the value of a noise indicator $\mathrm{L}_{\text {day }}$ could be estimated. According to Directive 2002/49/EC [4], $\mathrm{L}_{\text {day }}$ (day-noise indicator) is the A-weighted longterm average sound level as defined in ISO 1996-2 [25], determined over all day periods of a year and it is used as the noise indicator for annoyance during the day period.

Since this paper assumes that the observed traffic could be considered the yearly average, $\mathrm{L}_{\text {day }}$ could be estimated as LAeq noise level for the entire measurement period. This is done by combining the background noise levels measured and noise levels measured for each aircraft overflight as shown in Figure 7. For the first measurement period at the ML1, the estimated LAeq for the entire measurement period is $56.2 \mathrm{~dB}$ (Figure 7a), while for the second measurement period at the ML2 it is 66.9 $\mathrm{dB}$ (Figure $7 b$ ). To compare the estimated $\mathrm{L}_{\text {day }}$ values to the legal noise limits, it is crucial to know which acoustic zones the observed locations belong to. Acoustic zoning, as the main tool for directing and planning the use of a city's territory, implies classification of the territory of a city into zones with homogeneous limit values of noise indicators [30].

The Contract award notice for the "Belgrade acoustic zoning" public procurement with the Secretariat for Environmental Protection, City Administration of the City of Belgrade as the Contracting authority, states that the contract was signed on 27 August 2019 and that acoustic zoning for Belgrade will probably not be completed before December 2021. Even though Belgrade is not yet divided into acoustic zones, the territory around the selected measurement locations could be assigned to zones based on qualitative and quantitative approaches as described by Praščević et al. [30].

In the Republic of Serbia, there are six zones with homogeneous limit values for outdoor noise indicators, as shown in Table 5. Noise levels for day and evening time have equivalent limit values. It should be emphasized that limit values for outdoor noise indicators refer to total noise from all sources in the observed territory, and not only to aircraft noise. The territory around the selected measurement locations only has residential buildings in some parts, while 


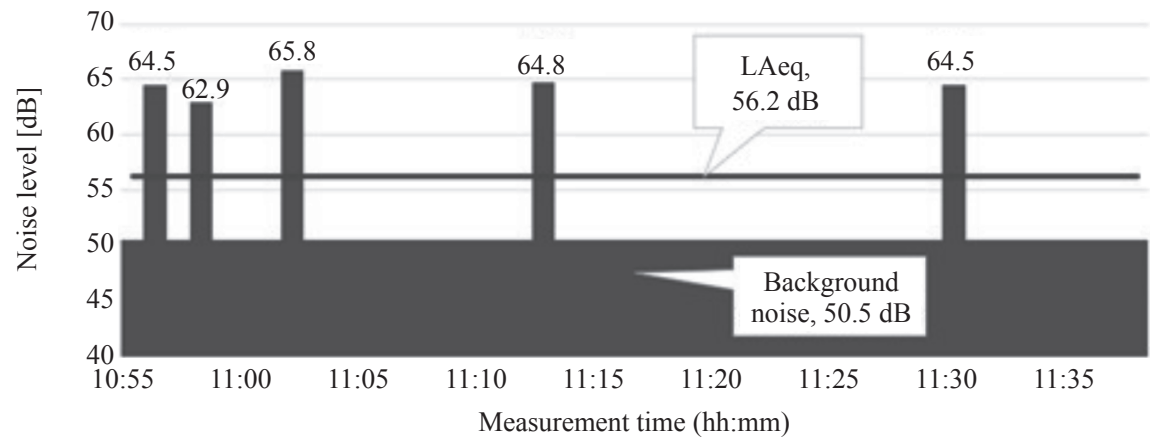

a) Noise levels at Measurement location 1

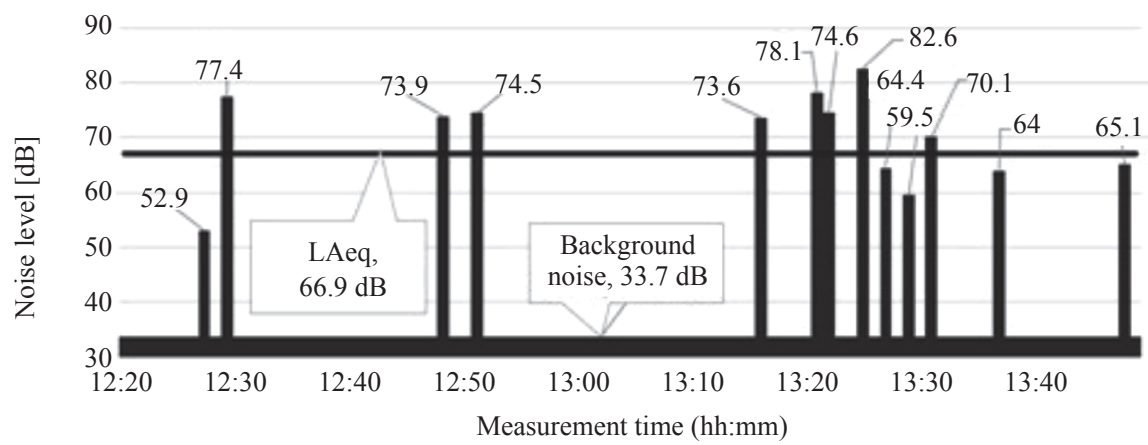

b) Noise levels at Measurement location 2

Figure 7 - Estimated LAeq for the measurement periods

in other parts of the settlements there are business, commercial and industrial zones with high traffic network. Therefore, it is not straightforward to decide which zone the selected measurement locations should belong to.

Consequently, all three zones that include residential areas and dwellings (Zones 3, 4 and 5) will be analyzed and discussed. If the ML1 and the ML2 are classified as pure residential areas, they would belong to Zone 3 and for both locations the measured noise levels would exceed the day limit noise value of $55 \mathrm{~dB}$. In case the locations are classified Table 5 - Limit values for outdoor noise indicators [31] as business-residential areas (Zone 4), which will most likely be the case considering the land use, the measured noise levels at the ML1 would be below the limit value of $60 \mathrm{~dB}$, while noise levels at the ML2 are still above the legal threshold. The same applies for Zone 5, where the noise limit value for daytime is $65 \mathrm{~dB}$.

This comparison was made based on two previously described assumptions and the assumption that the LAeq noise levels estimated for these measurements could be regarded as the $\mathrm{L}_{\text {day }}$ noise indicator for the selected locations. As such, the

\begin{tabular}{|c|l|c|c||}
\hline \multirow{2}{*}{ Zone } & \multicolumn{1}{|c|}{ Land use } & \multicolumn{2}{|c||}{ Noise level [dB] } \\
\cline { 3 - 4 } & & Day and evening & Night \\
\hline \hline 1 & $\begin{array}{l}\text { For rest and recreation, hospitals and recovery facilities, } \\
\text { cultural-historical locations, large parks }\end{array}$ & 50 & 40 \\
\hline 2 & Touristic areas, camps, and school zones & 50 & 45 \\
\hline 3 & Residential areas & 55 & 45 \\
\hline 4 & $\begin{array}{l}\text { Business-residential areas, commercial-residential areas, and children's } \\
\text { playgrounds }\end{array}$ & 60 & 50 \\
\hline 5 & $\begin{array}{l}\text { City center, trade, commercial, administrative zones with dwellings, } \\
\text { areas along the motorways, main roads, and city roads }\end{array}$ & 65 & 55 \\
\hline 6 & $\begin{array}{l}\text { Industrial, storage and servicing areas, and transport terminals without } \\
\text { dwellings }\end{array}$ & $\begin{array}{l}\text { At this area borders, noise must not exceed } \\
\text { the limit value of the neighboring area }\end{array}$ \\
\hline
\end{tabular}


presented analysis may indicate a possible exceedance of the noise levels prescribed by the law. However, detailed long-term noise measurements are needed to confirm such claim, which could help land use planners decide which zones these locations should be assigned to.

\section{CONCLUSION}

This research investigates the impact of aircraft noise on communities around the Belgrade Airport, based on the noise measured at two sound-sensitive community areas, Ledine and Ugrinovci. The measurement results presented in this paper clearly indicate that the noise issue in these settlements exists and that it cannot be neglected. All eighteen measurements performed showed that aircraft overflight noise levels differ by more than $10 \mathrm{~dB}$ from residual noise levels measured, which according to all relevant standards is considered to be significant.

More such short-term noise measurements are necessary to enable better insight into the noise situation around the Belgrade Airport. Nevertheless, a systematic approach to the noise issue through the balanced approach implementation is inevitable for the Belgrade Airport in the near future.

Apart from the noise abatement procedure published in the Aeronautical Information Publication for the Belgrade Airport, there are still neither publicly available reports of the actual efforts made towards the aircraft noise reduction nor the description of the current noise situation. This lack of information about the aircraft noise levels in the settlements around the Belgrade Airport makes independent analyses such as this research even more valuable to the researchers and general public.

One open issue that concerns the residents of the settlement Ledine the most is the status of illegal buildings/structures around the airport and the intention and legal obligation for Belgrade Airport to mitigate noise impact on these dwellings. To to estimate which dwellings are within the noise contours exceeding the noise limit values and for which dwellings the airport should be obliged to provide sound insulation and noise mitigation, the prerequisite is that such dwellings are legal and that it is known which acoustic zone they belong to. Since Belgrade is not yet divided into acoustic zones, preliminary compatibility analysis with acoustic zoning performed in this research could help land use planners classify the above-mentioned settlements into zones. Our results showed that under the given assumptions, it is evi- dent that noise levels in settlement Ledine are above the legal threshold for any selected zone, while in settlement Ugrinovci the noise level is either below or above the set limit depending on the zone selected. Traffic decrease due to Covid-19 pandemic will allow a timely reaction by the Belgrade Airport. Nevertheless, detailed long-term noise measurements are needed to confirm such claims and this result should be considered as an indicator that the acoustic zoning issue should be looked into in the near future.

Future research could also include a GIS based analysis of spatial and temporal impact of aircraft noise on vulnerable infrastructure, like schools and hospitals, with a proposed policy for alleviating noise vulnerability induced by the airport.

Forecasted air traffic growth at the Belgrade Airport will undoubtedly lead to an increase of negative aircraft noise impact on communities around the airport, especially the ones located exactly beneath the arrival and departure flight trajectories. To keep the aircraft noise levels within the legal limits and to improve the wellbeing of the residents living near the Belgrade Airport, continuous noise and flight tracks monitoring is required and aircraft noise abatement procedures are highly recommended whenever possible.

\section{ACKNOWLEDGEMENTS}

This research was supported by the Ministry of Education, Science and Technological Development of the Republic of Serbia and the Ministry of Science and Education of the Republic of Croatia. It also represents a part of the bilateral scientific and technological cooperation project between the Republic of Serbia and the Republic of Croatia for the period 2019-2020 named "Support to Sustainable Development of the Air Transport System". All the equipment used for sound measurement and analysis was kindly provided by the Laboratory for Aircraft Emissions of the Faculty of Transport and Traffic Sciences, University of Zagreb.

\section{Dr EMIR GANIĆ}

E-mail: e.ganic@sf.bg.ac.rs

Dr JURICA IVOŠEVIĆ ${ }^{2}$

E-mail: jivosevic@fpz.unizg.hr

Dr BOJANA MIRKOVIĆ ${ }^{1}$

E-mail: b.mirkovic@sf.bg.ac.rs

${ }^{1}$ Univerzitet u Beogradu, Saobraćajni fakultet Vojvode Stepe 305, 11000 Beograd, Srbija

2 Sveučilište u Zagrebu, Fakultet prometnih znanosti Vukelićeva 4, 10000 Zagreb, Hrvatska 


\section{UTICAJ BUKE VAZDUHOPLOVA NA NASELJENA MESTA U BLIZINI AERODROMA BEOGRAD}

\section{REZIME}

Cilj ovog istraživanja bio je da se ispita uticaj buke vazduhoplova na naseljena mesta u blizini Aerodroma Beograd sprovođenjem kratkotrajnih merenja buke. Osim postupka za smanjenje buke objavljenih u Zborniku vazduhoplovnih informacija za Aerodrom Beograd, još uvek ne postoje javno dostupni izveštaji o stvarnim naporima koji su preduzeti u cilju smanjenja buke vazduhoplova, niti opis trenutne situacije u vezi s bukom. Da bi se procenila trenutna situacija u vezi s bukom, izvršeno je osamnaest merenja buke preleta vazduhoplova $u$ određenim područjima dva naseljena mesta u okolini Aerodroma Beograd osetljivim na buku. Rezultati su pokazali razlike u nivou između pozadinske buke i preleta aviona bile veće od $10 \mathrm{~dB}$ za svako merenje i smatraju se značajnim. Takođe, sprovedena je preliminarna analiza kompatibilnosti sa akustičkim zoniranjem. Izvršena je procena prosečnih dnevnih nivoa buke na osnovu ovih kratkotrajnih merenja i poređenje sa graničnim vrednostima buke koje propisuje zakon za različite akustičke zone. Rezultati ukazuju da u nekim slučajevima nivoi buke premašuju zakonski prag, što bi trebalo da podstakne planere korišćenja zemljišta da na dnevni red uvrste pitanje akustičkog zoniranja Beograda, ali i da navede beogradski aerodrom da sprovodi kontinuirani monitoring buke i putanja leta.

\section{KLJUČNE REČI}

spoljašnja buka vazduhoplova; Aerodrom Beograd; merenje buke; monitoring buke; monitoring putanja leta; mere za smanjenje buke.

\section{REFERENCES}

[1] Ashford N, Stanton HP, Moore CA, Coutu P, Beasley JR. Airport Operations. New York: McGraw Hill; 2013.

[2] European Commission. Flightpath 2050 - Europe's vision for aviation: Maintaining global leadership and serving society's needs. Luxembourg: Publications Office of the European Union; 2012. p. 1-32. Available from: https:// op.europa.eu/s/n6cj

[3] ICAO. Doc 9829 - Guidance on the balanced approach to aircraft noise management. Second. Montreal, Canada: International Civil Aviation Organization; 2008.

[4] European Commission. Directive 2002/49/EC of the European parliament and the Council of 25 June 2002 relating to the assessment and management of environmental noise. Official Journal of the European Communities. 2002;189: 12-25.

[5] Vogiatzis K. Assessment of environmental noise due to aircraft operation at the Athens International Airport according to the 2002/49/EC Directive and the new Greek national legislation. Applied Acoustics. 2014 Oct;84: $37-$ 46. DOI: 10.1016/j.apacoust.2014.02.019
[6] Vogiatzis K. Airport environmental noise mapping and land use management as an environmental protection action policy tool. The case of the Larnaka International Airport (Cyprus). The Science of the Total Environment. 2012 May 1;424: 162-73. DOI: 10.1016/j.scitotenv.2012.02.036

[7] Licitra G, Gagliardi P, Fredianelli L, Simonetti D. Noise mitigation action plan of Pisa civil and military airport and its effects on people exposure. Applied Acoustics. 2014 Oct;84: 25-36. DOI: 10.1016/j.apacoust.2014.02.020

[8] Ozkurt N, Sari D, Akdag A, Kutukoglu M, Gurarslan A. Modeling of noise pollution and estimated human exposure around İstanbul Atatürk Airport in Turkey. The Science of the Total Environment. 2014 Jun;482-483: 48692. DOI: 10.1016/j.scitotenv.2013.08.017

[9] Ozkurt N, Hamamci SF, Sari D. Estimation of airport noise impacts on public health. A case study of İzmir Adnan Menderes Airport. Transportation Research Part D: Transport and Environment. 2015 May;36(July): 152-9. DOI: $10.1016 /$ j.trd.2015.02.002

[10] European Commission. COMMISSION DIRECTIVE (EU) 2015/996 of 19 May 2015 establishing common noise assessment methods according to Directive 2002/49/ EC of the European Parliament and of the Council. Official Journal of the European Union. 2015.

[11] Ho-Huu V, Ganić E, Hartjes S, Babić O, Curran R. Air traffic assignment based on daily population mobility to reduce aircraft noise effects and fuel consumption. Transportation Research Part D: Transport and Environment. 2019 Jul;72: 127-47. DOI: 10.1016/j.trd.2019.04.007

[12] Fahrländer SS, Gerfin M, Lehner M. The influence of noise on net revenue and values of investment properties investment properties: Evidence from Switzerland. Bern, Switzerland; 2015. Available from: https://www.econstor.eu/ handle/10419/126624

[13] Lawton RN, Fujiwara D. Living with aircraft noise: Airport proximity, aviation noise and subjective wellbeing in England. Transportation Research Part D: Transport and Environment. 2016 Jan;42: 104-18. DOI: 10.1016/j. $\operatorname{trd} .2015 .11 .002$

[14] Lim C, Kim J, Hong J, Lee S. Effect of background noise levels on community annoyance from aircraft noise. The Journal of the Acoustical Society of America. 2008 Feb;123(2): 766-71. DOI: 10.1121/1.2821985

[15] Black DA, Black JA, Issarayangyun T, Samuels SE. Aircraft noise exposure and resident's stress and hypertension: A public health perspective for airport environmental management. Journal of Air Transport Management. 2007 Sep;13(5): 264-76. DOI: 10.1016/ j.jairtraman.2007.04.003

[16] Janssen SA, Centen MR, Vos H, van Kamp I. The effect of the number of aircraft noise events on sleep quality. Applied Acoustics. 2014 Oct;84: 9-16. DOI: 10.1016/ j.apacoust.2014.04.002

[17] Sari D, Ozkurt N, Akdag A, Kutukoglu M, Gurarslan A. Measuring the levels of noise at the İstanbul Atatürk Airport and comparisons with model simulations. Science of The Total Environment. 2014 Jun;482-483(1): 472-9. DOI: 10.1016/j.scitotenv.2013.07.091

[18] Institute of Faculty of Transport and Traffic Engineering. [Measurement and analysis of noise generated by air traffic at Belgrade airport]. Belgrade, Serbia; 1975. Serbian 
[19] Institute of Faculty of Transport and Traffic Engineering. [Study of general project with zoning and noise generated by air traffic at Belgrade airport]. Belgrade, Serbia; 1978. Serbian

[20] Institute of Faculty of Transport and Traffic Engineering. [Impact of aircraft noise on settlement located western from "Dr Ivana Ribara" street]. Belgrade, Serbia; 1986. Serbian

[21] Institute of Faculty of Transport and Traffic Engineering. [Study of aircrfat noise in the vicinity of Belgrade airport and measures form noise mitigation]. Belgrade, Serbia; 1990. Serbian

[22] Mirković B. [Regulations and practice concerning noise-related restrictions in Serbia]. Tehnika. 2015;70(3): 501-8. Serbian. DOI: 10.5937/tehnika1503501M

[23] Ganić E, Radojević M, Babić O. Influence of aircraft noise on quiet areas. In: Proceedings of the $25^{\text {th }}$ International Conference Noise and Vibration, Tara, Serbia. University of Niš, Faculty of Occupational Safety; 2016. p. 47-53. Available from: https://www.researchgate.net/ publication/344083893

[24] International Organization for Standardization. ISO 20906 Acoustics - Unattended monitoring of aircraft sound in the vicinity of airports. First edition; 2009.

[25] International Organization for Standardization. ISO 1996-2 Acoustics - Description, measurement and assessment of environmental noise - Part 2: Determina- tion of sound pressure levels. Third edition; 2017.

[26] Rhodes D. Guidance on comparing calculated aircraft noise levels with measurements. UK Civil Aviation $\mathrm{Au}-$ thority; 2018 Dec.

[27] Ganić E, Babić O, Čangalović M, Stanojević M. Air traffic assignment to reduce population noise exposure using activity-based approach. Transportation Research Part D: Transport and Environment. 2018 Aug;63: 58-71. DOI: $10.1016 / j . t r d .2018 .04 .012$

[28] The City of Belgrade. [Half a century of existence of the settlement of Ledine has been marked]. Serbian. Available from: http://www.beograd.rs/index.php?lang=cir\&kat=beoinfo\&sub $=1465674 \% 3 \mathrm{f}$ [Accessed 9th Sep 2020].

[29] EUROCONTROL. The STATFOR Interactive Dashboard; 2020. Available from: https://www.eurocontrol. int/dashboard/statfor-interactive-dashboard

[30] Praščević M, Mihajlov D, Cvetkovic D, Gajicki A, Holecek N. Acoustic Zoning and Noise Assessment. Applied Mechanics and Materials. 2013 Sep;430: 244-50. DOI: 10.4028/www.scientific.net/AMM.430.244

[31] Službeni glasnik RS br. 75. Uredba o indikatorima buke, graničnim vrednostima, metodama za ocenjivanje indikatora buke, uznemiravanja i štetnih efekata buke u životnoj sredini. Službeni glasnik RS br. 75. Srbija; 2010. Serbian. 